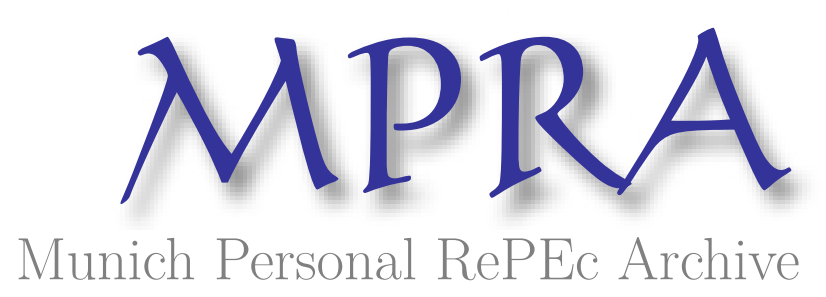

\title{
Has Knowledge Improved Economic Growth? Evidence from Nigeria and South Africa
}

Shobande, Olatunji and Asongu, Simplice

January 2021

Online at https://mpra.ub.uni-muenchen.de/110695/

MPRA Paper No. 110695, posted 15 Nov 2021 11:14 UTC 


\title{
$\underline{\text { A G D I Working Paper }}$
}

\section{$\mathrm{WP} / 21 / 059$}

\section{Has Knowledge Improved Economic Growth? Evidence from Nigeria and South Africa}

Forthcoming: Journal of Public Affairs

\author{
Olatunji A. Shobande \\ Business School, University of Aberdeen, UK \\ E-mails: olatunji.shobande@abdn.ac.uk / \\ o.shobande.19@abdn.ac.uk
}

Simplice A. Asongu

(Corresponding Author)

African Governance and Development Institute,

P. O. Box 8413, Yaoundé, Cameroon

E-mails: asongusimplice@yahoo.com

asongus@afridev.org 
Research Department

\title{
Has Knowledge Improved Economic Growth? Evidence from Nigeria and South Africa
}

\section{Olatunji A. Shobande \& Simplice A. Asongu}

January 2021

\begin{abstract}
This study examines whether knowledge causes economic growth in Africa's two leading economies: Nigeria and South Africa. Using the Vector Autoregressive and Vector Error Correction approach, the findings show cointegration among the variables. The speed of convergence of the variables to their long-term mean values is relatively higher for South Africa than for Nigeria. In the short run, it is observed that knowledge unidirectionally Granger causes growth for Nigeria, whereas bidirectional causality is observed for South Africa. The higher correlation between knowledge and growth in South Africa reflects the success of greater investment in education. Nigeria must increase investment in education and modern infrastructure to converge to South Africa's growth trajectory. Moreover, for Nigeria, (i) knowledge unidirectionally Granger cause growth, (ii) evidence of bidirectional causality flow is apparent between trade, the economic incentive and growth and (iii) health unidirectionally Granger cause knowledge. As for South Africa: (i) there is bidirectional causality between knowledge, trade openness and growth, whereas investment and economic incentive, unidirectionally Granger causes growth, (ii) investment, trade openness and health unidirectionally Granger cause knowledge and (iii) economic incentive unidirectionally Granger cause trade openness. In conclusion, this paper argues that a transformed education system can provide the knowledge base essential for promoting and sustaining economic growth.
\end{abstract}

Keywords: Convergence; Growth performance; Knowledge-based economy; Nigeria; South Africa JEL Classification: O10; O30; O38; O55; O57 


\section{Introduction}

There is no consensus among economists on whether knowledge accumulation significantly increases productivity and promotes economic growth ${ }^{1}$. Critics argue that it may in fact lead to problems such as overqualification (Kaur \& Singh, 2016; Molla \& Cuthbert, 2018), overproduction (Britz et al., 2006; Odunsi, 2018), and lack of skill development (Okafor, 2010; Janoski et al., 2014).

In the developing world, however, the blame for low productivity and growth may lie, not with knowledge accumulation, but with the inadequate financing of education and essential infrastructure. Evidence from Africa shows that despite knowledge accumulation, economic growth is not quantitative enough to accommodate the needs of the corresponding rising population (Asongu et al, 2019, 2020; Asongu \& Odhiambo, 2019, 2020a). This study aims to determine whether knowledge Granger causes growth in the two leading African economies - Nigeria and South Africa in order to provide policy insights on how sustainable growth can be promoted, inter alia, by means of the knowledge economy.

Beginning with Becker (1992, 1994) and Mankiw, Romer, and Weil (MRW) (1994), who recognized knowledge as crucial for increasing output and promoting economic growth, empirical literature on the role of the knowledge economy (KE) has continued to accumulate. Becker $(1976,1993,2007)$ developed and tested an economic framework that explains the role of knowledge in growth. Subsequently, MRW (1994) examined whether knowledge accumulation is responsible for international variations in standards of living; they discovered that, for the countries investigated, knowledge plays a critical role in economic growth. While the evidence in favour of the KE is relatively mixed; it is generally accepted that knowledge is created through technological innovation, with a long-run prospect of economic growth (Asongu \& Andres, 2020).

Recent studies by Becker (2007), the World Bank (2007), Asongu and Odhiambo (2019), and Nyarko (2013), provide new findings that warrant a re-examination. In particular, several studies (Anyanwu, 2012; Nyarko, 2013; Asongu. \& Odhiambo, 2020b; Tchamyou et al., 2019a) have provided consistent insights into the relevance of the KE for African growth.

\footnotetext{
${ }^{1}$ Growth and economic growth are used interchangeably throughout the study.
} 
However, most of them focus on specific regions and do not provide information on the trickle-down effects of KE, which could have helped in a comparative analysis of different countries. To bridge these gaps in the existing literature, this study presents comparative evidence on the KE in the two of Africa's largest economies, Nigeria and South Africa. Hence, this research departs from the extant literature on the subject by engaging a comparative study of the two largest economies in the continent of Africa.

There are three major reasons behind undertaking this analysis. First, the education sector is currently experiencing a huge transformation, ranging from a shift in the classroom approach to a digitalized economy, which has paved the way for re-examining the role of knowledge in these countries. The large investment required to improve research and training in educational institutions necessitate an inquiry into whether investment in KE will translate into growth. Second, most studies investigating causality have different mechanisms through which KE may lead to convergence, and revalidating the argument requires knowing which approach applies to Nigeria and South Africa. For example, there has been an increase in knowledge accumulation in Nigeria, but the investment does not reflect in its growth trend as has been consistently recorded (Joseph-Raji et al., 2018).

Conversely, South Africa has invested heavily in KE, but growth has been prolonged (Odunsi, 1996). Consequently, examining the linkages between KE and growth will resolve the growth dilemma in these African countries and help policy makers redesign the intervention programs needed to reposition their economies for growth. Hence, it is worthwhile to assess how the different experiences of Nigeria and South Africa in terms of investment in knowledge infrastructure and growth prospects withstand empirical scrutiny. Third, the notable transition in the KE has reshaped competition in knowledge accumulation. Hence, it is imperative and timely for policy makers to be informed on how the transition towards knowledge-based economies is shaping growth trajectories.

In the light of the above insights, the present study extends the empirical literature on the KE and makes the following contributions: (a) It explores whether the KE causes growth in Nigeria and South Africa, (b) By controlling for confounders, the study make inference on the causation links among the factors, and (c) using the Granger causality methodology, it helps decouple the short-and long-run dynamics among the factors to determine the rapid components and their convergence back to their long-term mean values. The findings indicate 
a long-run relationship in the KE determinant, in both datasets pertaining to Nigeria and South Africa. However, the rate of convergence of the variables for South Africa is relatively higher than that of Nigeria.

The rest of the study is structured as follows. Section 2 discusses the extant literature on the $\mathrm{KE}$ in Africa. Section 3 elaborates upon the data and methodology used. Section 4 presents the empirical results, and section 5 concludes with policy recommendations.

\section{Literature Review}

For decades, research seeking to determine whether the KE matters for economic growth have accumulated important findings and insights on human capital development, but major findings on the subject are still inconsistent and controversial. Nyarko (2013) examined the role of knowledge and economy structure in sustaining high economic growth in Sub-Saharan Africa (SSA). Nyarko's model on structural change, based on that of Hausmann et al. (2007), reported that the $\mathrm{KE}$ is critical for promoting growth across the different sectors, which subsequently improves productivity within SSA.

The work of Asongu and Andres (2020) work on the trajectory of the knowledge economy applied the four components of the KE index from the World Bank: economic incentives, innovation, education, and information infrastructure. The authors conclude that SSA and the Middle East and North African (MENA) countries have a low level of KE and suggested economic integration in these countries to promote knowledge spillovers in order to enable them to catch up with their more technically - advanced counterparts. Comparing the African countries with South Korea, Asongu and Tchamyou (2020) investigated the role of the KE, focusing on human capital, knowledge creation, knowledge diffusion, institutions, and economic incentives using sigma convergence for the period 1996-2010 and reported that the $\mathrm{KE}$ diagnosis provides a robust explanation among the countries investigated.

Asongu (2017) presents fresh South Korean lessons to Africa by assessing the knowledge economy gaps using 53 peripheral Africa countries decomposed into different features on wealth, legal origins, regional proximity, oil exporting, political instability and landlockedness. The scholar also exploits the four KE components which include education, innovation, information and communication technology (ICT) and economic incentives and 
reported that contemporary KE lessons from South Korea are as relevant as historic lessons to contemporary African nations.

In contrast, Ejemeyovwi and Osabuohien (2018) examined the relevance of KE, focusing on mobile technology and growth in West Africa for 1996-2012, using the generalized method of moments (GMM). They reported that human capital weakens innovation, which affects growth. Oluwatobi et al. (2020) examined the interaction between knowledge economic and economic growth in 32 SSA countries for the period 1996 to 2012, using the System GMM and reported that institutions and human capital in SSA mitigate effect of innovation on economic growth among the African countries examined.

Mohamed (2016) assessed the impact of the KE on long-term economic growth in the Egyptian economy for the period 1980-2014, using Granger causality to test the four components of the KE (i.e., human capital, innovation, economic growth, and institutional regime); the results indicate a causal relationship between the $\mathrm{KE}$ and economic growth. Voyvoda and Yeldan (2015) investigated and assessed the interactions between knowledgedriven growth, acquisition of human capital, and role of strategy in public policy for Turkey's economy and reported that the government expenditure on education and other capital investments have a direct link with growth in Turkey. Similarly, Edvinsson and Soderberg (2011) investigated the dynamics of the knowledge economy before the industrial revolution in Sweden and Western Europe and reported the price of essential goods as an important driver of the KE.

Given the diversity of evidence, it becomes clear that more information is required to validate the role of knowledge accumulation in the African economy. There is a dearth of empirical literature investigating the $\mathrm{KE}$ at country level; studies based on cross-sectional data provide inconsistent and conflicting results. Therefore, the main aim of the present study is to establish whether the KE matters for growth.

\section{Research Question}

Based on the above review of empirical studies and the proposed contribution of the present study to the extant literature discussed in the introduction, the research question for the present study is as follows: 
Does knowledge Granger cause economic growth in Nigeria and South Africa?

This research question will provide valuable insights on the need to strengthen the knowledge economy and policy in two of Africa's largest economies, Nigeria and South Africa.

\section{Data and Methodology}

This section presents the data and the research method. It provides information on the empirical model used and the statistical procedure implemented.

\section{Data}

This study examines whether knowledge Granger causes growth in Nigeria and South Africa for the period 1987-2019. The annual data sourced from the Central Bank of Nigeria (CBN) and the South African Reserve Bank (SARB) is used. The variables and measures used as well as their descriptions are stated below. Growth: it is measured by using gross domestic product (GDP) growth (annual \%). It reflects the productivity level of the economy and is suitable for international comparison (Asongu \& Nwachukwu, 2017).

Knowledge: it is captured as the investment in education. It is measured by the total government expenditure on education (current, capital, and transfers) (\% of GDP). It is useful for comparing the investment in knowledge across countries (Tchamyou, 2020). Investment: it is measured by gross capital formation (current US\$). It includes all the fixed assets of the economy, including schools, hospitals, and plants and machinery (Asongu et al., 2019, 2020).

Economic incentives: it is measured using the domestic credit provided by the financial sector (\% of GDP), including gross credit to various sectors (Tchamyou, 2017; Shobande \& Enemona, 2021). Health: it is measured as life expectancy at birth (total years). Life expectancy indicates the number of years a newborn infant would live if the mortality pattern remained the same throughout his/her life (Sira et al., 2020; Ogbeifun \& Shobande, 2021; Pasara et al., 2020; Becker, 2007, Ram, 2007). Trade openness: it is the sum of exports and imports of goods and services measured as a share of gross domestic product GDP) (Amavilah, 2009; Asongu et al., 2017, 2018; Asongu \& Andre, 2020; Asongu \& Nwachukukwu, 2017; Asongu \& Tchamyou, 2015; Ogbeifun \& Shobande, 2021). 


\section{Methodology}

The Model

Following the endogenous growth model, the relationship between $\mathrm{KE}$ and growth is specified in the Cobb Douglas function as:

$$
Y_{i, t}=K_{i, t}^{\alpha}\left(A_{i, t}\left(L_{i, t}\right)\right)^{\beta} \quad 0<\alpha<1
$$

Where $Y$ is output growth, $K$ is capital, $L$ is labour, and $A$ is efficiency or total factor productivity. $\alpha$ and $\beta$ are the elasticities of the factor inputs which are assumed to exhibit constant elasticity of substitution (CES) (i.e., $\alpha+\beta=1$ ), $i$ is the index of country and $t$ is time.

Following the Becker (2007) and MRW (1994) assumption that labour should be replaced with the human capital component to reflect the state of knowledge and education, we respecified the equation (1) as:

$$
Y_{t}=K_{t}^{\alpha}\left(A_{t}\left(H_{t}\right)\right)^{\beta}
$$

Where $H$ is substituted human capital (education and health), whereas the linearised form equation (2) is respecified as:

$$
\log Y_{t}=\log A_{t}+\alpha \log K_{t}+\beta \log H_{t}+v_{t}
$$

The linearised include the error term or shock proxy as $v$, and replace the elasticity with $\phi$ for uniformity and other controls covariate by aligning with components of KE index provided by World Bank. Thus, the model is respecified as:

$$
\log Y_{t}=\phi_{0}+\phi_{1} \log K_{t}+\phi_{2} \log H E_{t}+\phi_{3} \log K E_{t}+\phi_{4} \log E I_{t}+\phi_{5} \log T R_{t}+v_{t}
$$

Where $\phi_{0}$ is a constant parameter and $\phi_{1-5}$ are not only intercepts but also the elasticities of each associated variable, $K$ is a physical capital proxy with investment, $H E$ is health, $K E$ is education, $E I$ is an economic incentive (monetary policy), and $T R$ is trade openness.

\section{Time Series Modelling}

\section{Motivations}


This study is framed in a time series approach for the implementation of Granger causality. Specifically, the time series used to follow the VAR/ VEC Granger causality. Three reasons motivate the VAR/VEC Granger causality. First, it provides a yardstick for treating all the variables endogenously (Wang et al., 2020; Benk \& Gillman, 2020' Gahysels et al., 2020; Kin et al., 2020). Second, it helps to decompose the factors into short and long-run perspectives, providing information on their dynamic interaction (Mazzarisi et al., 2020; Shao et al., 2020; Wimmer et al., 2020). Third, it provides an avenue to assess the variable's convergence speed to equilibrium and the associated mechanism (Zhao et al., 2020; Liu et al., 2020; Massa \& Rosellon, 2020).

\section{Short-run VAR/VEC Granger Causality Model}

As stated earlier, the study is framed in VAR/VEC Granger causality and must fulfil two key assumptions before it can be implemented. First, the variables must be stationary at their first differences; second, there must be evidence of cointegration among the variables. Similarly, after cointegration has been determined, it is important to uncover the link between the series' long and short-run properties determined by the error correction term (ect). Consequently, the core relationship between short run, long run and error correction component is summarised, model from equation (4) and presented as follows in equation 5 - 10.

$$
\begin{aligned}
\log Y_{i, t}=\phi_{10} & +\sum_{k=1}^{p} \phi_{11 i k} \log Y_{i, t-k}+\sum_{k=1}^{p} \phi_{12 i k} \log K_{i, t-k}+\sum_{k=1}^{p} \phi_{13 i k} \log H E_{i, t-k} \\
& +\sum_{k=1}^{p} \phi_{14 i k} \log K E_{i, t-k}+\sum_{k=1}^{p} \phi_{15 i k} \log E I_{i, t-k}+\sum_{k=1}^{p} \phi_{16 i k} \log T R_{i, t-k} \\
& +\alpha_{1 i} E C M_{i t-1}+\mu_{1 i, t}(5) \\
\log K_{i, t}=\phi_{20} & +\sum_{k=1}^{p} \phi_{21 i k} \log K_{i, t-k}+\sum_{k=1}^{p} \phi_{22 i k} \log Y_{i, t-k}+\sum_{k=1}^{p} \phi_{23 i k} \log H E_{i, t-k} \\
& +\sum_{k=1}^{p} \phi_{24 i k} \log K E_{i, t-k}+\sum_{k=1}^{p} \phi_{25 i k} \log E I_{i, t-k}+\sum_{k=1} \phi_{26 i k} \log T R_{i, t-k} \\
& +\alpha_{2 i} E C M_{i t-1}+\mu_{2 i, t}(6)
\end{aligned}
$$




$$
\begin{aligned}
\log H E_{i, t}=\phi_{30} & +\sum_{k=1}^{p} \phi_{31 i k} \log H E_{i, t-k}+\sum_{k=1}^{p} \phi_{32 i k} \log K_{i, t-k}+\sum_{k=1}^{p} \phi_{33 i k} \log Y_{i, t-k} \\
& +\sum_{k=1}^{p} \phi_{34 i k} \log K E_{i, t-k}+\sum_{k=1}^{p} \phi_{35 i k} \log E I_{i, t-k}+\sum_{k=1}^{p} \phi_{36 i k} \log T R_{i, t-k} \\
& +\alpha_{3 i} E C M_{i t-1}+\mu_{3 i, t}(7)
\end{aligned}
$$

$$
\begin{aligned}
\log K E_{i, t}=\phi_{40} & +\sum_{k=1}^{p} \phi_{41 i k} \log K E_{i, t-k}+\sum_{k=1}^{p} \phi_{42 i k} \log K_{i, t-k}+\sum_{k=1}^{p} \phi_{43 i k} \log H E_{i, t-k} \\
& +\sum_{k=1}^{p} \phi_{44 i k} \log Y_{i, t-k}+\sum_{k=1}^{p} \phi_{45 i k} \log E I_{i, t-k}+\sum_{k=1}^{p} \phi_{46 i k} \log T R_{i, t-k} \\
& +\alpha_{4 i} E C M_{i t-1}+\mu_{4 i, t}(8)
\end{aligned}
$$

$$
\begin{aligned}
\log E I_{i, t}=\phi_{50} & +\sum_{k=1}^{p} \phi_{51 i k} \log E I_{i, t-k}+\sum_{k=1}^{p} \phi_{52 i k} \log K_{i, t-k}+\sum_{k=1}^{p} \phi_{53 i k} \log H E_{i, t-k} \\
& +\sum_{k=1}^{p} \phi_{54 i k} \log K E_{i, t-k}+\sum_{k=1}^{p} \phi_{55 i k} \log Y_{i, t-k}+\sum_{k=1}^{p} \phi_{56 i k} \log T R_{i, t-k} \\
& +\alpha_{5 i} E C M_{i t-1}+\mu_{5 i, t}(9)
\end{aligned}
$$

$$
\begin{aligned}
\log T R_{i, t}=\phi_{60} & +\sum_{k=1}^{p} \phi_{61 i k} \log T R_{i, t-k}+\sum_{k=1}^{p} \phi_{62 i k} \log K_{i, t-k}+\sum_{k=1}^{p} \phi_{63 i k} \log H E_{i, t-k} \\
& +\sum_{k=1}^{p} \phi_{64 i k} \log K E_{i, t-k}+\sum_{k=1}^{p} \phi_{65 i k} \log E I_{i, t-k}+\sum_{k=1}^{p} \phi_{66 i k} \log Y_{i, t-k} \\
& +\alpha_{6 i} E C M_{i t-1}+\mu_{6 i, t}(10)
\end{aligned}
$$

In equation $5-10, \phi_{10}, \phi_{20}, \phi_{30}, \phi_{40}, \phi_{50}, \phi_{60}$ are taken as constants associated with an individual model for each variable; $\phi_{11-16}, \phi_{21-26}, \phi_{31-36}, \phi_{41-46}, \phi_{51-56}, \phi_{61-66}$ are parameters and elasticities for each model associated with endogenous factors; $p$ represents the lag lengths and its decay with decreasing $k$; and $E C M_{i t}$ is the speed of convergence of 
the variables to the long term means and $\alpha$ is the elasticity or velocity of each of the equations.

\section{Empirical Results}

In this section, we estimate whether knowledge cause growth in Nigeria and South Africa using the VAR/VEC Granger causality approach and discuss the corresponding of results, before comparing the attendant results with previous studies.

\section{Preliminary Checks}

Here, we examined the descriptive statistics and correlation matrix of the series used in the study. The goal is to have information on the series' prior behaviour, which is deemed important before undertaking any robust analysis. The summary statistics are presented in Table 1, while the correlation matrix is reported in Table 2.

"Table 1 here"

According to Nigeria's descriptive statistics, the mean value and standard deviation of the GDP growth rate are about 4.5 (3.8). Consistently for the other variables: knowledge (KE) 1.4 (0.25); health (HE), 48.7 (2.4); investment (K), 4.1 (2.6); economic incentive (EI), 196.1 (34.8) and trade openness (TR) 36 (9.3). For South Africa, the GDP growth rate and the corresponding standard deviation stood at 2.2 (1.94), and consistently for some other variables: knowledge (KE) is 3.1 (1.07) and health (HE) 59.4 (13.7).

\section{Correlation Matrix}

The goal of this section is to check the correlation matrix of the variable used. The correlation provides information on the kind and nature of the association among the variables. The report of the correlation matrix is reported in Table 1.

"Table 2 here"

\section{Unit root test- $\mathrm{Ng}$ Perron Test}

This section aims to conduct unit roots tests on the series used for the analysis. It is important to have information on the stochastic properties of the variables used. Also, overlooking this 
check may lead to spurious regression, if the variable is non-stationary. Similarly, information about the mean, variance and autocovariance of each lag is essential for policy purpose. Simultaneously, the precise unit test conducted to follow the $\mathrm{Ng}$ and Perron (2001) Modified statistic procedure. Three reasons motivate our use of $\mathrm{Ng}$ Perron unit root test. First, it provides an avenue for checking our series' long trend cycle by decomposition of time. Second, $\mathrm{Ng}$ and Perron test stresses the importance of long-run variance in series behaviour and help choose appropriate lag lengths that conform to the series' good size and power properties (Philip, 1987; Perron \& Ng, 1996). The Ng and Perron primary properties summarised in $M_{t}$ and decomposed into three tests: $M Z_{\alpha}, M Z_{t}$ and $M S B$, statistically expressed in equation (11-12):

$$
\begin{gathered}
M Z_{\alpha}=\left[\left(T^{-1} y_{T}^{2}-S_{A R}^{2}\right)\left(2 T^{-2} \sum_{t=1}^{T} y_{t-1}^{2}\right)^{-1}\right], \\
M S B=\left|\left(T^{-1} \sum_{t=1}^{T} y_{t-1}^{2} /_{S_{A R}^{2}}\right)\right|
\end{gathered}
$$

The $M Z_{\alpha}, M Z_{t}$ and $M S B$ are assumed to be an autoregressively estimate of the spectral density at frequency zero (see $\mathrm{Ng}$ and Perron, 2001; Perron 1996). The $M$ test for $p=0$ and 1 are taken from the least squares obtained. The results of the Ng-Perron unit root test conducted are reported in Table 3.

\section{"Table 3 here"}

According to the $\mathrm{Ng}$ - Perron unit root test results for Nigeria and South Africa, the variable was not stationary at level. To circumvent this shortcoming and ensure stationarity of the series, we used the trend stationary and differencing stationary series. After the transformation process, the series was then stationary. Thus, we conclude that the variables' stationarity was induced by differencing and is integrated at order one.

\section{VAR Lag Selection Criteria}


In this section, select our optimal lag length using the Akaike information criteria (AIC), Hannan-Quinn information (HQ), and Bayesian information criterion (BIC). The corresponding results are reported in Table 4. According to the optimal lag selection results, most of the statistical criteria admitted that lag 2 is the optimal lag length for the variables in Nigeria and South Africa.

\section{"Table 4 here"}

\section{Johansen Cointegration Test}

The goal of this section is to test for cointegration among the variables used for the analysis. Specifically, the Johansen (1991) cointegration test was implemented. The approach assesses whether there is evidence of a linear combination among the candidate variables employed. To conduct the cointegration test, we have used the lag values in the proceeding section to test for cointegration, and the results are reported in Table 5. For Nigeria, the results indicate four cointegrated equations, whereas for South Africa five cointegrated equations are apparent. Based on the suggested cointegration result from the T-value of the trace statistics, we conclude that the variables can revert to their long-run mean.

\section{"Table 5 here"}

\section{VAR/VEC Granger Causality Tests}

The Granger causality proposed and developed by Granger (1969) is used in this analysis. Two reasons satisfied the implementation of the method. First, $\mathrm{Ng}$ - Perron tests confirmed that the dataset is stationary. Second, the Johansen cointegration test also confirmed that the variables are cointegrated. The specific Granger causality used is framed in VAR/VEC Granger causality or Block exogeneity Wald tests. The approach enables us to uncover the short run, long run and the speed of the convergence of the variables to their long term mean values, summarised in Table 6.

\section{"Table 6 here"}

Four main findings can be deduced for Nigeria. (a) there is evidence of short - and long-run relationships among the variables, (b) the error correction term (ect) showing the speed of convergence of the variables to their long-run mean values is negative and statistically 
significant, but relatively slow, (c) knowledge (KE) unidirectionally Granger cause growth (GDP), (d) evidence of bidirectional causality flow was observed between trade, the economic incentive (EI) and growth (GDP), (e) health (HE) unidirectionally Granger cause knowledge.

Consistently, five findings can be deduced for South Africa, (a) there was evidence of cointegration among the factors, (b) the velocity of the variables to their equilibrium position was relatively high, (c) observed bidirectional causality between knowledge (KE) trade openness (TR) and growth (GDP) was apparent; whereas investment (K), the economic incentive (EI), unidirectionally Granger causes growth, (d) investment and trade openness (TR), heath (HE) unidirectionally Granger cause knowledge, (e) economic incentive unidirectionally Granger cause trade openness (TR).

Now we compare Nigeria's results with those of South Africa in order to reveal the lesson on the relationship between knowledge and growth. First, evidence shows a unidirectional causality flow from knowledge to growth in Nigeria, whereas bidirectional causality was observed for South Africa. Second, the speed of convergence of the variables to their longterm mean was slow in Nigeria compared to South Africa. Third, both variables in the two countries have short- and long-run properties.

The finding has some policy implications for Nigeria. First, there is unidirectional causality observed in Nigeria, indicating that knowledge can indeed help to promote growth. Yet, the country recorded consistent negative growth for two decades (Joseph-Raji et al., 2018). It would appear that poor investment in key infrastructure may have contributed to the abysmal growth performance observed. Second, evidence on the bidirectional relation between health and knowledge is an indication that the Nigerian economy cannot survive without proper investment in health and knowledge. This is because it is most likely healthy people that seek education and contribute to economic growth. Third, the existence of a long-run potential relationship between knowledge and growth in Nigeria indicates that if an investment is channelled to the educational sector, the country can meet up with its counterpart in the growth trajectory. However, the speed of convergence calls for concern as it would appear to be relatively slow. The velocity raises critical questions on policy response, as this may give 
rise to prolonged economic growth, which can be attributed to delay in convergence of the variables to their long-term mean.

The implication of the finding on the relationship between knowledge and growth in South Africa is explained from three standpoints. First, the bidirectional causality observed shows that notable growth in South Africa, whereas reports show that reforms are needed as educational inequality is prominent (Ferreira \& Gignoux, 2014). However, recent report has shown that education inequality is prominent. Of course, the economic intuition that investing in knowledge can promote growth has actually reflected that more intervention programs are needed to improve the contribution of knowledge as the country's growth trajectory has been slow in the past two decades.

Second, the channel through which knowledge affects South Africa's growth has been identified as investment, trade openness, and economic incentive. There is overwhelming evidence that trade openness and the financial sector's robustness have contributed to the growth recorded (see, Odhiambo, 2004; Odhiambo \& Nyasha, 2020; Tchamyou et al., 2019b). Third, the evidence on the unidirectional causality between health and education indicates that investment in the health sector is important for preserving its future human resources in the country. Fourth, one plausible explanation for the higher speed of convergence in South Africa compared to Nigeria is the disparity in quality of education between the countries. Therefore, policy makers should prioritise education investment in order to foster long term growth.

\section{Conclusion and future research directions}

Knowledge is generally referred to as the engine that drives growth. Although recent evidence has indicated that knowledge may be a source of problems, such as overqualification and overproduction, scholars have argued that the structure of the economy, and not knowledge accumulation, is the primary constraint (Britz et al., 2006, Okafor, 2010; Janoski et al., 2014).In this study, we have explored whether knowledge Granger causes growth in the two leading African economies. Our study has contributed to the existing empirical literature on the knowledge economy in the following ways. 
First, the methodological approach has been framed using VAR/VEC Granger causality. This approach enabled the examination of the dynamic relationships among the factors that decouple the short-and long-run components, and the error correction term, that reflects the rapid adjustment of the variables to their equilibrium position. Second, our findings confirmed that a long-run relationship exists among the variables, but the speed of adjustment was relatively higher for South Africa than for Nigeria. Similarly, it was observed that knowledge unidirectionally Granger causes growth for Nigeria, whereas evidence of bidirectional Granger causality was observed for South Africa.

The findings of this study have several implications for sampled countries. For Nigeria, there is evidence that knowledge can help the country in catching-up with its targeted growth trajectory. However, intervention programs, such as education financing and investment in modern infrastructure must necessarily bridge the existing gaps in growth. Similarly, the observed bidirectional causality for South Africa is evidence that investment in education has a feedback effect on growth. However, more knowledge financing is required to promote efficiency and speed-up the increase in productivity. Finally, it is not enough to increase the population's access to learning opportunities without also focusing on the skill development required to sustain economic growth, which justifies this study's position. A plausible explanation for the higher speed of convergence in South Africa compared to Nigeria is the disparity in quality of education between the countries. Therefore, policy makers should prioritise education investment in order to foster long term growth.

Another major implication of this study is that the economic structures should be tailored to be consistent with the education system such that knowledge produced and human resources resulting from these educational systems are put in good use for economic growth and structural transformation. Accordingly, such consistency is in accordance with the structure-system theory within the remit of the educational system depending on the structure of the economy for economic growth imperatives and vice-versa. Such inter-dependences between economic growth and knowledge as have been established in this study are nonetheless contingent on time-dynamic elements (i.e. short run versus long run) as well as on the involvement of other factors or variables in the modelling exercise. These theoretical and practical contingencies emphasize the importance of not adopting blanket policies, but conditioning such policies on the discussed specificities.

The findings in this study obviously leave room for future research, especially as it pertains to assessing how the established findings withstand empirical scrutiny in other 
African countries. Accordingly, engaging country-specific studies as has been done in this study is worthwhile for more targeted and/or country-specific implications. Moreover, considering other panel and country-specific empirical strategies to assess the validity of these findings is a worthwhile future research endeavour. While investment in education is used to capture knowledge, other proxies for knowledge should be considered in future research in the light of some contemporary studies (Galindo \& Mendez, 2014; Kose et al., 2020).

Table 1

Summary Statistics

\begin{tabular}{|c|c|c|c|c|c|}
\hline \multirow[b]{2}{*}{ Variables } & \multicolumn{2}{|c|}{ Nigeria } & \multicolumn{2}{|c|}{ South Africa } & \multirow[b]{2}{*}{ Obs. } \\
\hline & Mean & Std. Dev. & Mean & Std. Dev. & \\
\hline$G D P$ & 4.5 & 3.8 & 2.2 & 1.94 & 33 \\
\hline$K E$ & 1.4 & 0.25 & 3.1 & 1.07 & 33 \\
\hline$H E$ & 48.7 & 2.4 & 59.4 & 13.7 & 33 \\
\hline$K$ & 4.1 & 2.6 & 5.1 & 2.3 & 33 \\
\hline$E I$ & 196.1 & 34.8 & 152.5 & 32.86 & 33 \\
\hline$T R$ & 36 & 9.3 & 53.15 & 3.73 & 33 \\
\hline
\end{tabular}

Table 2

Correlation Matrix

\begin{tabular}{|c|c|c|c|c|c|c|}
\hline \multicolumn{7}{|c|}{ Nigeria } \\
\hline & $G D P$ & $K E$ & $H E$ & $K$ & $E I$ & $T R$ \\
\hline$G D P$ & 1 & & & & & \\
\hline$K E$ & 0.06 & 1 & & & & \\
\hline$H E$ & 0.05 & 0.15 & 1 & & & \\
\hline$K$ & 0.19 & 0.09 & 0.7 & 1 & & \\
\hline$E I$ & 0.12 & 0.33 & 0.8 & 0.72 & 1 & \\
\hline$T R$ & 0.24 & 0.18 & 0.17 & 0.01 & 0.13 & 1 \\
\hline & $G D P$ & $K E$ & $\begin{array}{c}\text { South Africa } \\
H E\end{array}$ & $K$ & $E I$ & $T R$ \\
\hline$G D P$ & 1 & & & & & \\
\hline$K E$ & 0.2 & 1 & & & & \\
\hline$H E$ & 0.5 & 0.18 & 1 & & & \\
\hline$K$ & 0.1 & 0.6 & 0.11 & 1 & & \\
\hline$E I$ & 0.25 & 0.7 & 0.46 & 0.68 & 1 & \\
\hline $\mathrm{TR}$ & 0.27 & 0.6 & 0.30 & 0.68 & 0.77 & 1 \\
\hline
\end{tabular}

Notes.GDP, growth; KE, knowledge; HE, health; $K$, gross capital formation (investment); EI, the economic incentive (monetary policy); TR, trade openness. 
Table 3.

Ng-Perron Modified Unit Root Test

\begin{tabular}{ccccc}
\hline \multirow{2}{*}{ Variables } & \multicolumn{2}{c}{ Nigeria } & \multicolumn{2}{c}{ South Africa } \\
\cline { 2 - 5 } & $M Z_{\alpha}$ & $\Delta M Z_{\alpha}$ & $M Z_{\alpha}$ & $\Delta M Z_{\alpha}$ \\
GDP & $1(0)$ & $1(1)$ & $1(0)$ & $1(1)$ \\
$K E$ & -5.5 & $-12.4^{* *}$ & -5.2 & $15.1^{* *}$ \\
$H E$ & -5.3 & $-9.3^{* *}$ & -3.8 & $-15.4^{* *}$ \\
$K$ & -5.4 & $-8.9^{* *}$ & 0.05 & $-6.7^{* *}$ \\
$E I$ & -4.1 & $-6.1^{* *}$ & -4.5 & $8.15^{* *}$ \\
$T R$ & -0.56 & $-12.03^{* *}$ & -0.8 & $14.2^{* *}$ \\
& 4.3 & $-14.7^{* *}$ & 4.02 & $15.3^{* *}$ \\
Critical value & $1 \%$ & -13.8000 & & \\
& $5 \%$ & -8.10000 & & \\
& $10 \%$ & -5.70000 & & \\
& & & &
\end{tabular}

Notes.GDP, growth; KE, knowledge; HE, health; $K$, gross capital formation (investment); EI, economic incentive (monetary policy); TR, trade openness. *** (**) denotes the rejection of null hypothesis at 1\% (5\%) significant level. $\Delta$ Symbolises that the variable is in first difference.

Table 4.

VAR Lag Selection Criteria

\begin{tabular}{|c|c|c|c|c|c|c|}
\hline \multicolumn{7}{|c|}{ Nigeria } \\
\hline Lag & $\log L$ & LR & FPE & $\mathrm{AIC}$ & $\mathrm{SC}$ & HQ \\
\hline 0 & -1169.715 & NA & $3.53 e+25$ & 75.85257 & 76.13012 & 75.94304 \\
\hline 1 & -990.7220 & 277.1501 & $3.64 \mathrm{e}+21$ & 66.62723 & $68.57005^{*}$ & 67.26054 \\
\hline 2 & -930.7919 & $69.59634 *$ & $1.03 \mathrm{e}+21 *$ & $65.08335^{*}$ & 68.69144 & $66.25950 *$ \\
\hline \multicolumn{7}{|c|}{ South Africa } \\
\hline Lag & $\log L$ & LR & FPE & AIC & $\mathrm{SC}$ & HQ \\
\hline 0 & -1212.254 & NA & $5.49 \mathrm{e}+26$ & 78.59704 & 78.87459 & 78.68751 \\
\hline 1 & -1035.800 & 273.2193 & $6.68 e+22$ & 69.53548 & 71.47830 & 70.16879 \\
\hline 2 & -936.3273 & $115.5167 *$ & $1.48 \mathrm{e}+21 *$ & $65.44047 *$ & $69.04857 *$ & $66.61662 *$ \\
\hline
\end{tabular}

Notes. *Indicates the lag order selected. LR: sequentially modified LR test statistic (each test is at the 5\% level), FPE: Final prediction error, HQ: Hannan-Quinn information criterion, AIC: Akaike and SC: Schwarz information criterion. 
Table 5.

Johansen Cointegration (Trace test) for Nigeria and South Africa

\begin{tabular}{ccccc}
\hline $\begin{array}{c}\text { Hypothesised No } \\
\text { of CE }\end{array}$ & Eigenvalue & Trace Statistics & Critical Value & Prob** \\
None $*$ & 0.890935 & 200.1884 & 95.75366 & 0.0000 \\
At most $1 *$ & 0.798658 & 133.7141 & 69.81889 & 0.0000 \\
At most $2 *$ & 0.697960 & 85.63154 & 47.85613 & 0.0000 \\
At most $3 *$ & 0.604302 & 49.71570 & 29.79707 & 0.0001 \\
At most $4 *$ & 0.499814 & 21.90260 & 15.49471 & 0.0047 \\
& & & & \\
Hypothesised No & Eigenvalue & Trace Statistics & Critical Value & Prob** \\
of CE & & & $5 \%$ & \\
None * & 0.981392 & 243.1644 & 95.75366 & 0.0000 \\
At most $1 *$ & 0.839417 & 123.6394 & 69.81889 & 0.0000 \\
At most $2 *$ & 0.612209 & 68.77107 & 47.85613 & 0.0002 \\
At most $3 *$ & 0.522969 & 40.35240 & 29.79707 & 0.0021 \\
At most $4 *$ & 0.366240 & 18.14718 & 15.49471 & 0.0195 \\
At most $5 *$ & 0.138276 & 4.464618 & 3.841466 & 0.0346 \\
\hline
\end{tabular}

*denotes rejection of the hypothesis at the 0.05 level. ** Mackinnon-Hang-Michalis (1999) values 
Table 6.

VAR/VEC Granger Causality/Block Exogeneity Wald Tests

\begin{tabular}{|c|c|c|c|c|c|c|c|}
\hline $\begin{array}{c}\text { Independent } \\
\text { Variable }\end{array}$ & \multicolumn{6}{|c|}{$\begin{array}{c}\text { The Direction of Causality for Nigeria } \\
\text { Dependent variable }\end{array}$} & $\begin{array}{l}\text { Long run } \\
\text { VECT }_{t-i}\end{array}$ \\
\hline$\Delta G D P_{t-i}$ & $\begin{array}{c}\Delta G D P_{t} \\
-\end{array}$ & $\begin{array}{c}\Delta K E_{t} \\
0.92 \\
{[0.17]}\end{array}$ & $\begin{array}{c}\Delta H E_{t} \\
1.99 \\
{[0.61]}\end{array}$ & $\begin{array}{c}\Delta K_{t} \\
0.85 \\
{[0.18]}\end{array}$ & $\begin{array}{c}\Delta E I_{t} \\
8.33^{* *} \\
{[0.03]}\end{array}$ & $\begin{array}{l}\Delta T R_{t} \\
5.6^{* *} \\
{[0.00]}\end{array}$ & $\begin{array}{c}V E C T_{t-i} \\
-0.03^{*} \\
(0.0)\end{array}$ \\
\hline$\Delta K E_{t-i}$ & $\begin{array}{l}3.6^{* *} \\
{[0.00]}\end{array}$ & - & $\begin{array}{l}18.0 * * \\
{[0.00]}\end{array}$ & $\begin{array}{c}2.9 \\
{[0.62]}\end{array}$ & $\begin{array}{l}1.01 \\
{[0.51]}\end{array}$ & $\begin{array}{c}3.7 \\
{[0.27]}\end{array}$ & $\begin{array}{c}-0.5^{* *} \\
(0.1)\end{array}$ \\
\hline$\Delta H E_{t-i}$ & $\begin{array}{l}6.0 * * \\
{[0.00]}\end{array}$ & $\begin{array}{l}5.90 * * \\
{[0.00]}\end{array}$ & - & $\begin{array}{c}2.7 \\
{[0.24]}\end{array}$ & $\begin{array}{c}1.90 \\
{[0.22]}\end{array}$ & $\begin{array}{l}28.1 * * \\
{[0.00]}\end{array}$ & $\begin{array}{c}0.018 * * \\
(0.00)\end{array}$ \\
\hline$\Delta \boldsymbol{K}_{t-i}$ & $\begin{array}{l}8.3^{* *} \\
{[0.00]}\end{array}$ & $\begin{array}{c}0.16 \\
{[0.26]}\end{array}$ & $\begin{array}{l}13.8^{* *} \\
{[0.00]}\end{array}$ & - & $\begin{array}{c}4.20 \\
{[0.30]}\end{array}$ & $\begin{array}{c}0.3 \\
{[0.19]}\end{array}$ & $\begin{array}{c}0.001 * \\
(0.0)\end{array}$ \\
\hline$\Delta E \boldsymbol{I}_{t-\boldsymbol{i}}$ & $\begin{array}{l}6.7 * * \\
{[0.00]}\end{array}$ & $\begin{array}{l}10.1^{* *} \\
{[0.00]}\end{array}$ & $\begin{array}{l}6.0 * * \\
{[0.00]}\end{array}$ & $\begin{array}{l}6.6^{* *} \\
{[0.00]}\end{array}$ & - & $\begin{array}{c}0.75 \\
{[0.33]}\end{array}$ & $\begin{array}{c}5.4 \\
(0.7)\end{array}$ \\
\hline$\Delta T R_{t-i}$ & $\begin{array}{c}21.6 * * * \\
{[0.00]}\end{array}$ & $\begin{array}{l}6.4 * * \\
{[0.00]}\end{array}$ & $\begin{array}{c}0.87 \\
{[0.17]}\end{array}$ & $\begin{array}{l}9.2 * * \\
{[0.00]}\end{array}$ & $\begin{array}{c}1.37 \\
{[0.25]}\end{array}$ & - & $\begin{array}{l}2.49^{* *} \\
(0.2)\end{array}$ \\
\hline $\begin{array}{l}\text { Independent } \\
\text { Variable }\end{array}$ & & & $\begin{array}{r}\text { Direction } \\
D \epsilon\end{array}$ & $\begin{array}{l}\text { ausality } \\
\text { lent vari }\end{array}$ & South Aj & & Long run \\
\hline$\Delta G D P_{-i}$ & $\Delta G D P_{t}$ & $\begin{array}{l}\Delta K E_{t} \\
7.8^{* *} \\
{[0.00]}\end{array}$ & $\begin{array}{c}\Delta H E_{t} \\
0.27 \\
{[0.27]}\end{array}$ & $\begin{array}{c}\Delta K_{t} \\
0.43 \\
{[0.33]}\end{array}$ & $\begin{array}{c}\Delta E I_{t} \\
1.27 \\
{[0.45]}\end{array}$ & $\begin{array}{c}\Delta T R_{t} \\
7.14^{* *} \\
{[0.00]}\end{array}$ & $\begin{array}{c}V E C T_{t-1} \\
-0.10^{* *} \\
(0.0)\end{array}$ \\
\hline$\Delta K E_{t-i}$ & $\begin{array}{c}4.63 * * \\
{[0.00]}\end{array}$ & - & $\begin{array}{c}3.0 \\
{[0.45]}\end{array}$ & $\begin{array}{l}4.1 * * \\
{[0.00]}\end{array}$ & $\begin{array}{c}2.06 \\
{[0.19]}\end{array}$ & $\begin{array}{c}1.87 \\
{[0.50]}\end{array}$ & $\begin{array}{c}-0.04 * * \\
(0.01)\end{array}$ \\
\hline$\Delta H E_{t-i}$ & $\begin{array}{c}0.94 \\
{[0.42]}\end{array}$ & $\begin{array}{l}12.0 * * \\
{[0.00]}\end{array}$ & - & $\begin{array}{l}8.5^{* *} \\
{[0.00]}\end{array}$ & $\begin{array}{l}7.61 * * \\
{[0.00]}\end{array}$ & $\begin{array}{c}0.59 \\
{[0.58]}\end{array}$ & $\begin{array}{c}0.002 * * \\
(0.00)\end{array}$ \\
\hline$\Delta \boldsymbol{K}_{t-i}$ & $\begin{array}{l}29.4 * * \\
{[0.00]}\end{array}$ & $\begin{array}{l}5.68 * * \\
{[0.00]}\end{array}$ & $\begin{array}{l}3.63 * * \\
{[0.00]}\end{array}$ & - & $\begin{array}{c}3.46 \\
{[0.69]}\end{array}$ & $\begin{array}{c}0.12 \\
{[0.18]}\end{array}$ & $\begin{array}{c}-0.05^{* *} \\
(0.00)\end{array}$ \\
\hline$\Delta E I_{t-i}$ & $\begin{array}{c}15.9 * * * \\
{[0.00]}\end{array}$ & $\begin{array}{c}3.66 \\
{[0.28]}\end{array}$ & $\begin{array}{c}2.26 \\
{[0.19]}\end{array}$ & $\begin{array}{c}0.31 \\
{[0.91]}\end{array}$ & - & $\begin{array}{c}19.36^{* *} \\
{[0.00]}\end{array}$ & $\begin{array}{c}-0.20 \\
(0.2)\end{array}$ \\
\hline$\Delta T R_{t-i}$ & $\begin{array}{l}5.02 * * \\
{[0.00]}\end{array}$ & $\begin{array}{l}6.62 * * \\
{[0.00]}\end{array}$ & $\begin{array}{c}2.94 \\
{[0.66]}\end{array}$ & $\begin{array}{c}0.76 \\
{[0.17]}\end{array}$ & $\begin{array}{c}1.39 \\
{[0.52]}\end{array}$ & - & $\begin{array}{l}-0.28 \\
(0.2)\end{array}$ \\
\hline
\end{tabular}

Notes.GDP, growth; KE, knowledge; HE, health; $K$, gross capital formation (investment); $E I$, the economic incentive (monetary policy); TR, trade openness. $* * *(* *)$ denotes the rejection of null hypothesis at $1 \%(5 \%)$ significant level.

\section{Data Availability Statement}

The data that support the findings of this study are available on request from the corresponding author. 


\section{References}

Anyanwu, J. C. (2012). Developing knowledge for the economic advancement of Africa. International journal of academic research in economics and management sciences, 1(2), 73-111.

Amavilah, V. H. S. (2009). Knowledge of African countries: production and value of doctoral dissertations. Applied Economics, 41(8), 977-989.

Andrés, A. R., Asongu, S. A., \&Amavilah, V. (2015). The impact of formal institutions on knowledge economy. Journal of the Knowledge Economy, 6(4), 1034-1062.

Asongu, S. A. (2017). Knowledge economy gaps, policy syndromes, and catch-up strategies: Fresh South Korean lessons to Africa. Journal of the Knowledge Economy, 8(1), 211-253.

Asongu, S. A., \& Andrés, A. R. (2020). Trajectories of knowledge economy in SSA and MENA countries. Technology in Society, 63, 101119.

Asongu, S. A., Anyanwu, J. C., \&Tchamyou, V. S. (2019). Technology-driven information sharing and conditional financial development in Africa. Information Technology for Development, 25(4), 630-659.

Asongu, S. A., \& le Roux, S. (2017). Enhancing ICT for inclusive human development in Sub-Saharan Africa. Technological Forecasting and Social Change, 118, 44-54.

Asongu, S. A., Tchamyou, V. S., \& Acha-Anyi, P. N. (2020). Who is who in the knowledge economy in Africa? Journal of the Knowledge Economy, 11(2), 425-457.

Asongu, S. A., \& Tchamyou, V. S. (2020). Human capital, knowledge creation, knowledge diffusion, institutions and economic incentives: South Korea versus Africa. Contemporary Social Science, 15(1), 26-47.

Asongu, S. A., \& Tchamyou, V. S. (2016). The impact of entrepreneurship on knowledge economy in Africa. Journal of Entrepreneurship in Emerging Economies, 8(1), pp. 101-131.

Asongu, S. A., \& Odhiambo, N. M. (2019). Basic formal education quality, information technology, and inclusive human development in sub-Saharan Africa. Sustainable Development, 27(3), 419-428.

Asongu, S. A., \& Odhiambo, N. M. (2020a). The role of globalisation in modulating the effect of environmental degradation on inclusive human development. Innovation: The European Journal of Social Science Research, 1-21.

Asongu, S. A., \& Odhiambo, N. M. (2020b). Building knowledge-based economies in Africa: A systematic review of policies and strategies. Journal of the Knowledge Economy, 11(4), $1538-1555$.

Becker, G. S. (1992). Human capital and the economy. Proceedings of the American philosophical society, 136(1), 85-92. 
Becker, G. S. (1994). Human capital revisited. In Human Capital: A Theoretical and Empirical Analysis with Special Reference to Education, Third Edition (pp. 15-28). The University of Chicago Press.

Becker, G. S. (2007). Health as human capital: synthesis and extensions. Oxford Economic Papers, 59(3), 379-410.

Becker, G. S., Murphy, K. M., \& Tamura, R. (1990). Human capital, fertility, and economic growth. Journal of political economy, 98(5, Part 2), S12-S37.

Becker, G. S., \& Tomes, N. (1986). Human capital and the rise and fall of families. Journal of labor economics, 4(3, Part 2), S1-S39.

Benk, S., \& Gillman, M. (2020). Granger predictability of oil prices after the Great Recession. Journal of International Money and Finance, 101, 102100.

Britz, J. J., Lor, P. J., Coetzee, I. E. M., \& Bester, B. C. (2006). Africa as a knowledge society: A reality check. The International information \& library review, 38(1), 25-40.

Edvinsson, R., \&Söderberg, J. (2011). Prices and the growth of the knowledge economy in Sweden and Western Europe before the industrial revolution. Scandinavian Economic History Review, 59(3), 250-272

Ejemeyovwi, J. O., Osabuohien, E. S., \&Osabohien, R. (2018). ICT investments, human capital development and institutions in ECOWAS. International Journal of Economics and Business Research, 15(4), 463-474.

Galindo, M-A., \& Mendez, M. T., (2014). Entrepreneurship, economic growth, and innovation: Are feedback effects at work? Journal of Business Research, 67(5), 825-829.

Granger, C. W. (1969). Investigating causal relations by econometric models and crossspectral methods. Econometrica: Journal of the Econometric Society, 424-438.

Ghysels, E., Hill, J. B., \&Motegi, K. (2020). Testing a large set of zero restrictions in regression models, with an application to mixed frequency Granger causality. Journal of Econometrics, 218(2), 633-654.

Ferreira, F. H., \&Gignoux, J. (2014). The measurement of educational inequality: Achievement and opportunity. The World Bank Economic Review, 28(2), 210-246.

Hausmann, R., Hwang, J., \& Rodrik, D. (2007). What you export matters. Journal of economic growth, 12(1), 1-25.

Janoski, T., Luke, D., \& Oliver, C. (2014). The causes of structural unemployment: Four factors that keep people from the jobs they deserve. John Wiley \& Sons.

Johansen, S. (1991). Estimation and hypothesis testing of cointegration vectors in Gaussian vector autoregressive models. Econometrica: Journal of the Econometric Society, 1551-1580. 
Joseph-Raji, G. A., Timmis, E., Meky, M. S., Rufai, M. A., Loevinsohn, B. P., Pinto, S. C., ... \& Mohammed, A. G. (2018). Investing in Human Capital for Nigeria's Future (No. 132316, pp. 1-0). The World Bank.

Kaur, M., \& Singh, L. (2016). Knowledge in the economic growth of developing economies. African Journal of Science, Technology, Innovation and Development, 8(2), 205212.

Kim, J. M., Lee, N., \& Hwang, S. Y. (2020). A copula nonlinear Granger causality. Economic Modelling, 88, 420-430.

Kose, N., Bekun, F. V., \& Alola, A. A., (2020). Criticality of sustainable research and development-led growth in EU: the role of renewable and non-renewable energy, Environmental Science and Pollution Research, 27, 12683-12691.

Liu, Y., Chen, H. S., Wu, H., Dai, Y., Yao, Y., \& Yan, Z. (2020). Simplified Granger causality map for data-driven root cause diagnosis of process disturbances. Journal of Process Control, 95, 45-54.

Mankiw, N. G., Romer, D., \& Weil, D. N. (1992). A contribution to the empirics of economic growth. The quarterly journal of economics, 107(2), 407-437.

Massa, R., \&Rosellón, J. (2020). Linear and nonlinear Granger causality between electricity production and economic performance in Mexico. Energy Policy, 142, 111476.

Mazzarisi, P., Zaoli, S., Campajola, C., \& Lillo, F. (2020). Tail Granger Causalities and Where to Find Them: Extreme Risk Spillovers vs Spurious Linkages. Available at SSRN 3591958 .

Mohamed, G. (2016). The Impact of Knowledge Economy on Economic Growth in Egyptian Economy. Magellan al-Tanmiyatwa-al-Siyasat al-Iqtisadiyyat, 18(2), 7-43.

Molla, T., \& Cuthbert, D. (2018). Re-imagining Africa as a knowledge economy: premises and promises of recent higher education development initiatives. Journal of Asian and African Studies, 53(2), 250-267.

Ng, S., \& Perron, P. (2001). Lag length selection and the construction of unit root tests with good size and power. Econometrica, 69(6), 1519-1554.

Nyarko, Y. (2013). Sustaining high economic growth in Sub-Saharan Africa: knowledge and the structure of the economy. Journal of African Economies, 22(suppl_1), i77-i101.

Okorafor, C. N. (2010). Challenges confronting libraries in documentation and communication of indigenous knowledge in Nigeria. The International Information \& Library Review, 42(1), 8-13

Odunsi, B. A. (1996). An analysis of brain-drain and its impact on manpower development in Nigeria. Journal of Third World Studies, 13(1), 193-214. 
Odhiambo, N. M. (2004). Is financial development still a spur to economic growth? A causal evidence from South Africa. Savings and Development, 28(1), 47-62.

Odhiambo, N. M., \& Nyasha, S. (2020). Is tourism a spur to economic growth in South Africa? An empirical investigation. Development Studies Research, 7(1), 167-177.

Oluwatobi, S., Olurinola, I., Alege, P., \& Ogundipe, A. (2020). Knowledge-driven economic growth: the case of Sub-Saharan Africa. Contemporary Social Science, 15(1), 62-81.

Pasara, M. T., Mutambirwa, T. K., \&Diko, N. (2020). The Trivariate Causality among Education, Health, and Economic Growth in Zimbabwe. Sustainability, 12(4), 1-15.

Perron, P., \& Ng, S. (1996). Useful modifications to some unit root test with dependent errors and their local asymptotic properties. The Review of Economic Studies, 63(3), 435-463.

Phillips, P. C. (1987). Time series regression with a unit root. Econometrica: Journal of the Econometric Society, 55(2), 277-301.

Ram, R. (2007). IQ and economic growth: Further augmentation of Mankiw-Romer-Weil model. Economics Letters, 94(1), 7-11.

Shao, L., Hu, W., \& Yang, D. (2020). The price relationship between main-byproduct metals from a multiscale nonlinear Granger causality perspective. Resources Policy, 69, 101846.

Širá, E., Vavrek, R., KravčákováVozárová, I., \& Kotulič, R. (2020). Knowledge-Economy Indicators and Their Impact on the Sustainable Competitiveness of the EU Countries. Sustainability, 12(10), 4172.

Tchamyou, V. S. (2019). The role of information sharing in modulating the effect of financial access on inequality. Journal of African Business, 20(3), 317-338.

Tchamyou, V. S. (2017). The role of knowledge economy in African business. Journal of the Knowledge Economy, 8(4), 1189-1228.

Tchamyou, V. S. (2020). Education, lifelong learning, inequality and financial access: Evidence from African countries. Contemporary Social Science, 15(1), 7-25.

Tchamyou, V. S., Asongu, S. A., \& Odhiambo, N. M. (2019a). The role of ICT in modulating the effect of education and lifelong learning on income inequality and economic growth in Africa. African Development Review, 31(3), 261-274.

Tchamyou, V. S., Erreygers, G., \& C assimon, D., (2019b). Inequality, ICT and Financial Access in Africa, Technological Forecasting and Social Change,139 (February), 169-184.

Teixeira, P. N. (2014). Gary Becker's early work on human capital-collaborations and distinctiveness. IZA Journal of Labor Economics, 3(12), 1-20.

Voyvoda, E., \&Yeldan, E. (2015). Public policy and growth in Canada: An applied endogenous growth model with human and knowledge capital accumulation. Economic Modelling, 50, 298-309. 
Wang, N., Guo, J., Liu, X., \& Fang, T. (2020). A service demand forecasting model for oneway electric car-sharing systems combining long short-term memory networks with Granger causality test. Journal of Cleaner Production, 244(January), 118812.

Wimmer, T., Geyer-Klingeberg, J., Hütter, M., Schmid, F., \& Rathgeber, A. (2020). The impact of speculation on commodity prices: A Meta-Granger analysis. Journal of Commodity Markets, 100148.

Zhao, L., Wen, F., \& Wang, X. (2020). Interaction among China carbon emission trading markets: Nonlinear Granger causality and time-varying effect. Energy Economics, 91, 104901. 